\title{
1. Human resource management in emerging markets: an introduction
}

\author{
Frank Horwitz and Pawan Budhwar
}

\section{INTRODUCTION}

The shifting of global economic power from mature, established markets to emerging markets (EMs) is a fundamental feature of the new realities in the global political economy. Due to a combination of reasons (such as scarcity of reliable information on management systems of EMs, the growing contribution of human resource management (HRM) towards organisational performance, amongst others), the understanding about the dynamics of management of HRM in the EMs context and the need for proactive efforts by key stakeholders (e.g., multinational and local firms, policy makers and institutions such as trade unions) to develop appropriate HRM practice and policy for EMs has now become more critical than ever. It is more so given the phenomenal significance of the EMs predicted for the future of the global economy. For example, Antoine van Agtmael predicts that:

in about 25 years the combined gross national product (GNP) of emergent markets will overtake that of currently mature economies causing a major shift in the centre of gravity of the global economy away from the developed to emerging economies. (van Agtmael 2007: 10-11)

Despite the present (late 2013 and early 2014) slowdown in the contribution of EMs towards the global industrial growth (e.g., Das, 2013; Reuters, 2014), EMs are predicted to produce 70 per cent of world GDP growth and a further ten years later, their equity market capitalisation is expected to reach US\$ 80 trillion, 1.2 times more than the developed world (see Goldman Sachs, 2010). Further, in aggregate they will be nearly twice as large as the current developed economies (van Agtmael, 2007: 12). In this context, it is debatable (see van Agtmael, 2007; Horwitz and Mellahi, 2009) the extent to which the paradigm of EMs and the developed/developing construct will be able to explain the fundamental shift of power under way. The economic primacy of Western developed countries is no longer a given as these nations are no longer 
able to take unilateral decisions affecting emerging economies. As van Agtmael (2007) concludes, it is a matter of time before a block of emerging economies headed by China increasingly calls the shots on global geopolitical and economic issues, as for example occurred at the United Nations climate change conference in Copenhagen in December 2009. Emerging markets at present account for more than 50 per cent of global economic output and emerging market MNCs (EMMNCs) like Tata, Infosys and Wipro of India, Exarro Resources, Glencore, Naspers, SABMiller, Sasol and Sappi from South Africa, Haier in China, Embraer and CVRD in Brazil, and Hyundai and Samsung in Korea, are now global players (Horwitz and Mellahi, 2009).

Such developments have global implications, in particular for issues related to employment, war for talent, diversity and inclusion, emergence of EMMNCs, and integration of initiatives such as BRICS (Brazil, Russia, India, China and South Africa), CIVET (the acronym coined by Michael Geoghegan, former chief executive of HSBC to cluster another group of middle-income emerging markets: Colombia, Indonesia, Vietnam, Egypt and Turkey), and MINT (Mexico, Indonesia, Nigeria and Turkey). For example, as the EMs move from the global economic periphery to the centre it is changing the distribution and character of global jobs. As per an ILO Report (2011), globally there are about 3 billion employees, of which 2.8 billion are employed in developing and EMs. In order to sustain such employment and economic growth firms based in EMs are experiencing massive pressures for continuous salary increases, and need to invest heavily in training as the graduates in EMs lack employable skills, despite a regular increase in the number of graduates produced. This results in a war for talent. Further, it is predicted that China will have an employee shortage of 20 million by 2030 (for details see Berger, 2012). Nevertheless, a significant number of highly educated women are entering the global workforce, which in particular in the EMs context raises the serious challenges of diversity and inclusion (see Hewlett and Rashid, 2011). Further, the EMMNCs, which are growing at a rapid speed, are struggling with the issue of 'employer branding' (where jobseekers prefer to work in developed countries' MNCs over EMMNCs). In the globalised world, there are also HR issues related to the key determinants of HRM policies and practices in different EMs, the context-specific challenges faced by HR managers in different EMs' set-ups, issues of convergence-divergence or crossvergence, and so on. This volume assembles contributions which will provide the reader with a good understanding about such issues.

Against such a background, this chapter has four aims: first, building on the above, it will further provide a rationale for the need for this book; 
second, in order to put things in context, it presents an overview regarding the meaning of EMs, the opportunities they provide for global business and also indicate the challenges of doing business in them. This section also provides a brief on EMMNCs; third, it summarises the key developments in HRM in EMs; fourth, it introduces the chapters of this volume.

As indicated, for a variety of economic, political and social reasons, there has been an enhanced interest of both researchers and the practitioners in EMs in general and in the dynamics of management of HR in particular. However, we understand there is no robust publication which provides a comprehensive overview regarding the nature and pattern of HRM systems of firms operating in a variety of EMs. Indeed, there is a significant and growing body of work published in leading journals and lately in books on different aspects of HRM in specific EMs such as China, India, and South Africa, and now evolving work on Russia, Mexico and Brazil, amongst others. But there are fewer books which bring together leading experts in international human resource management focusing specifically on the latest research and HRM trends in EMs. We believe this volume fills a real need in this regard.

It is also particularly relevant in light of the rapid developments in the field of HRM and its increased acceptance as an important contributor towards organisational performance, which combined with the growing importance of EMs demands the need to examine and highlight the relevant HRM systems for the EMs' context. This will contribute both to better theory and practice development. Given the unique sociocultural, political, legal and economic milieu of each EM, the challenges regarding the efficient management of HRs in them can be both complex and demanding. In this regard, scholars can play a significant role by providing relevant information to both policy makers and researchers. Such knowledge is also important for business students to gain an understanding of the different issues relating to HRM in EMs.

Thus, the objective of this book is to provide the reader with an understanding of the dynamics of HRM in EMs in the present global context. It is intended that the reader acquires not only an understanding about the present and emerging HRM functions in EMs, but also awareness of the diverse and unique configurations of national factors (cultural, institutional and business environment), which dictate HRM in the EMs set-up. Such awareness will enable the reader to better understand the 'context-specific' nature of HRM. This book then consolidates in a single source the dynamics of management of human resources in the EMs context, i.e., questions pertaining to the 'what', 'why', 'how' and 'when' of HRM in EMs. 


\section{EMERGING MARKETS}

Briscoe (2013) differentiates between various types of emerging markets and further distinguishes them from developed countries or mature markets. The late 1960s nomenclature for certain of these markets in Asia was the Asian Tiger economies. These included South Korea, Singapore, Hong Kong and Taiwan. He notes that these economies enabled high economic growth through export-drive strategies. Many of these have today become mature, high-income developed economies (Singapore for example). Growth in such economies was facilitated by state investment in education, skills and infrastructure development, and incentives to attract foreign direct investment (FDI) in sectors such as manufacturing. These were often strongly state-directed capitalist economies. Briscoe (2013: 2-3) then refers to the Asian Tiger Cubs, which developed in the 1980s as a subset of larger Asian economies. This group included countries like Indonesia, Malaysia, the Philippines and Thailand. They followed similar growth strategies as the erstwhile Asian Tigers with a strong emphasis on infrastructure development, growing IT capabilities and enhancing education.

The BRICS nations are the largest grouping of inter-continental powerhouses of emerging middle-income economies. They have the world's largest populations, especially India and China, with rapid growth until a more recent slowdown. They are increasingly characterised by trade and tariff agreements and direct investment with each other and others. For example, China now is the biggest single foreign direct investor in Africa.

Bailey (2010) and Briscoe (2013: 3) refer to the N-11 grouping, which they note might join the Asian Tigers and BRICS. These countries also have large populations, increased economic growth and enhanced GDP rates. They include Egypt, Mexico, Indonesia, Vietnam, the Philippines, Nigeria, Pakistan, Turkey, Iran and Bangladesh and sometimes South Korea, although it can be argued that the latter has developed into a mature economy able to join the OECD group of developed countries defined by having a per capita GDP of at least $\$ 34,000$.

Given the diversity of economic growth (amongst other factors), a simple definition of emerging markets is not helpful, and there might come a time when this concept too becomes less robust. It might for example be argued that China is today the second largest economy in the world, but it is still considered 'emerging'. Large populations with an average lower per capita income (such as China and India) still suggest that in terms of large-scale human development, poverty and inequality 
reduction, even the large BRICS countries can therefore still be considered as 'emerging markets'. These are complex, transitional societies with diverse economic models, demographic, cultural, linguistic and ethnicity mixes and difficult challenges of human and infrastructure development. The countries that constitute EMs in whatever classification is used are then unique and different, and defy broad and simplistic generalisations. From this complexity and diversity emanate Emerging Market Multinational Companies (EMMNCs) steeped in working with these issues in order to survive and indeed prosper. This arguably provides a measure of resilience, which this book argues positions them strongly and adroitly in international markets.

\section{Emerging Markets Growth}

Jim O'Neill of Goldman Sachs suggested the term 'growth markets' for defining an emerging economy that accounts for more than 1 per cent of global GDP. Today this would extend to other rapidly growing countries including Indonesia, Mexico, Ghana, Nigeria, South Korea and Turkey. What sets them apart is not their size or growth but the combination of both. The combined GDP of the BRICS might exceed $\$ 95$ trillion by 2050. That is more than six times the size of Americas' economy (The Economist, 2011a: 84).

Our book focuses not only on the BRICS countries but also on other emerging markets including some of those dubbed the CIVETS. Once dubbed as 'the hopeless continent' by The Economist magazine, anaemic growth in mature markets has made sub-Saharan Africa an attractive destination for foreign direct investment, which has increased by around 50 per cent since 2005 . The IMF predicts that this continent will continue to grow at 5 per cent or more, faster than most other regions (The Economist, 2012b: 49). The notion of 'middle income' earnings level is one feature of an 'emerging market'. In terms of JP Morgan index, a country may qualify for emerging market 'status' if its people have had low or middle incomes for at least two years. Nigeria after South Africa became the second country in Africa to join JP Morgan's local emerging market government-debt index (The Economist, 2012d: 77).

According to OECD projections, by 2060, economic power will have tilted even more decisively away from mature rich economies, with the fast catch up of lesser developed economies with large populations (The Economist, 2012d: 77). In 2011 the current membership of the OECD made up 60 per cent of global output, compared with a combined 24 per cent for China and India. By 2060 these two Asian countries will have a 46 per cent share of world GDP and the OECD members' share will have 
reduced to 42 per cent. Combined, their economies will be bigger than that of the United States, a conclusion consistent with that of van Agtmael (2007). However, this does not mean that individuals will necessarily be better off in these emerging markets. Because of their large populations, countries like China and India will see increases in per capita GDP but in China, for example, GDP per person will be at around 59 per cent of that in America and in India it will be only 27 per cent, and Brazil and South Africa 40 per cent, Mexico 45 per cent and Russia 46 per cent, according to OECD purchasing power parity figures. Emerging markets are also seeing the development of new geopolitical and regional groupings for trade and investment.

South-South relations such as these emerging between Brazil and African countries are developing, for example, 'Brazil in Africa' (The Economist, 2012a: 70-71). Brazilian agribusinesses are also investing in Africa, for example the large MNC Vale in coal mining in Mozambique. Mining operation in Mozambique is its largest outside Brazil. Odebrecht was involved in the construction of the Capanda Dam in Angola and built Angola's first shopping mall in Luanda. Petrobras, Brazil's state owned multinational is in the oil industry in Angola and Nigeria and in exploration in other African countries such as Benin, Gabon, Libya, Nigeria and Tanzania. Brazilian construction firms are also active in ports, housing and sanitation projects in Angola, Congo and Guinea. In the consumer industry, O Boticario, a Brazilian cosmetics firm, has been selling its products in Africa since 2006. In 2001, Brazil invested $\$ 69$ billion in Africa, which increased to $\$ 214$ billion by 2009 . Unlike China, which also has invested more significantly in Africa, Brazil does not require Africa's mineral resources, but rather seeks to diversify its global markets.

Table 1.1 The BRICS countries selected economic indicators (\%)

\begin{tabular}{lcccc}
\hline Indicator & Brazil & Russia & India & China \\
\hline GDP growth & 2.7 & 4.3 & 7.2 & 9.2 \\
Inflation & 6.6 & 8.4 & 8.6 & 5.4 \\
Unemployment & 5.0 & 6.5 & 9.8 & 4.0 \\
Investment/GDP & 20.6 & 23.2 & 34.4 & 48.3 \\
Savings/GDP & 18.4 & 28.6 & 31.6 & 51.0 \\
Current-Account balance/GDP & -2.1 & 5.5 & -2.8 & 2.8 \\
Budget balance/GDP & -2.6 & 1.6 & -8.7 & -1.2 \\
\hline
\end{tabular}

Sources: IMF and Economist Intelligence Unit reported in The Economist, 29 September 2012. 
Although South Africa is not included in Table 1.1, as a recent member of the BRICS group comparatively it has a lower GDP growth of 2.3 per cent and particularly high unemployment at 25.5 per cent, current account balance of -6.2 per cent/GDP and budget balance/GDP of -4.8 (The Economist, 2012c: 100). It is by far the smallest of the BRICS countries and underperforms in several of these comparative indicators. These quantitative indicators are significant barometers of socioeconomic and HRM issues. For example, the 2012 mining industry strikes in South Africa which saw more than 30 miners lose their lives, was not merely about wages increase demands but more fundamentally about the large socio-economic inequalities in that society. The Gini coefficient measure of income inequality has shown inequality in South Africa at 0.63 , higher than in 1994 when it became a full democracy in contrast to other African countries where it is reducing. Narrowing of income related inequality is a significant challenge for EM incomes, remuneration and social spending policies, but also that of public policy which enables a fairer 'trickle-down effect' of higher economic growth. Latin American countries have seen inequalities in their region reduce as a result of a surge in secondary school education, state investment in universities and increases in demand for semi-skilled workers in labour intensive sectors such as building and construction (Lustig, 2012).

Sub-Saharan Africa collectively has average incomes of $\$ 1,700$ per capita, though this is still a relatively low middle-income threshold. Reasons for this rise in per capita incomes include rapid urbanisation, rising longevity in most countries, impact of technology such as mobile communications and improved governance (Fengler, 2012).

Labour markets of countries such as India, in spite of its relatively high GDP over the past decade (slowing down to around 5 per cent in 2015), also reveal significant human resource development challenges. Some 97 per cent of school-age children enrol, though over half drop out before completing high school. This is despite a new law, the Right to Education Act, aimed at setting minimum education standards, which is being introduced (The Economist, 2012b: 11). Huge skills shortages exist, for example with only 500,000 civil engineers when the country needs nearly 4 million, according to The Economist (2012b: 11). Further estimates are that by the mid-2020s India will have a bigger population than China. It has a high fiscal deficit of nearly 9 per cent and FDI slowed down in 2012 dropping by 67 per cent from a record $\$ 47$ billion in 2011 (The Economist, 2012b: 4), though this increased in 2013. These and above discussed factors are important and form part of the analysis in various chapters in this book. Also significant in this regard is the rise of EMMNCs. 


\section{The Growth of Emerging Market Multinational Companies (EMMNCs)}

The Boston Consulting Group analysed 100 leading firms from emerging markets (The Economist, 2011b: 79). Firms from the BRICS countries dominate this list. These firms have seen revenues grow by 18 per cent per annum and have expanded fast without sacrificing profit margins. Examples of such firms include the Tata Group from India, Grupo Bimbo from Brazil - the world's largest baker, meat producer IBS from Brazil, aluminium manufacturer United Company RUSAL of Russia and telecoms-equipment firms Huawei Technologies and ZTE from China. Several of these firms have bought Western companies such as Lenovo's purchase of IBM's PCs. A feature of this growth is a mix of mergers and acquisitions and joint ventures, the latter occurring especially where EMMNCs venture into other EMs such as China and African countries. In both these instances, joint ventures may be with state-run enterprises and other EM enterprises. Such an initiative has been pointed out as the way forward by Nobel laureate Stiglitz, which will contribute to both economic and employment generation (PTI, 2014).

PetroChina (an energy firm), ChinaMobile (telecommunications) and ICBC and CCB (Chinese banks) were listed in the top ten of the world's most valuable companies (The Economist, 2013d). China's major private Internet firm Alibaba has also become a significant international player and has been buying up Internet sites in America (The Economist, 2013d: 68). Also, an Afro-Asian nexus is increasingly occurring given significant investment by Chinese MNCs in Africa and strategic alliances between Chinese and African firms such as Naspers and the Chinese Internet and mobile company Ten Cent; as well as between Naspers and Russian Internet firms. Together EMs now have more than 1,000 firms with annual sales of over $\$ 1$ billion (The Economist, 2013d: 68). A contemporary development is the influence of private firms and not only traditional state-run enterprises from China in international markets. A shift is underway in China's overseas direct investment. The first wave was largely by state-owned firms, and directed at acquiring commodities, minerals and energy resource from other developing markets. A second wave is investment in mature developed economies. Examples of these include Fosun International, a Chinese conglomerate acquiring 1 Chase Manhattan Plaza for \$725 million. China has invested in Thames Water and Heathrow Airport in the UK, and recently in a planned nuclear plant. Geely, a Chinese car manufacturer, bought Volvo of Sweden (The Economist, 2013b: 70-72). This Afro-Asian nexus is not limited to China. Similarly, India has quietly become a second major investor in 
Africa. Indian-African ties go back some time and include Mahatma Gandhi spending two decades in South Africa. Recently major Indian MNCs such as Tata Group, Bharti Enterprise and Essar have invested in African countries. Indian firms spent $\$ 2.6$ billion in a share of a Mozambican oilfield and have invested more than $£ 1$ billion in the agricultural sector in Ethiopia. Karuturi Global, the world's largest producer of cut flowers, employs 5,000 people in Kenya. These relations underscore the benefits of 'South-South' cooperation. The Indian government has offered more than $\$ 10$ billion in loan programmes to finance trade and investment by Indian firms in Africa. There is also a planned $\$ 14$ billion trade and investment programme between South Africa and India (The Economist, 2013c: 55-56).

According to Chattopadhyay et al. (2012) EMMNCs have two basic advantages - economies of scale and local knowledge - often with low-cost manufacturing competences, e.g., HTC, Natura cosmetics of Brazil and Wipro of India. Building global brands does, however, take time with clearly articulated and differentiated strategies, including niche strategies, mergers and acquisitions, focus on similar emerging markets and gradualism, for example the approach adopted by Mahindra \& Mahindra (Chattopadhyay et al., 2012: 55-57).

\section{Human Resource Management in Emerging Markets}

For economic development and growth to be sustainable in the long term, EMs still have massive human resource and infrastructural development challenges (Kamoche et al., 2004: xvi). There is indeed a paucity of published work on HRM in EMs in general and EMMNCs in particular (see Zupan and Kase, 2005; Horwitz, 2012). As mentioned above, there is indeed an emerging body of relevant literature, for example, the region-specific HRM books pursued under the Global HRM series by Routledge (e.g., on Africa by Kamoche et al., 2004; on Asia-Pacific by Varma and Budhwar, 2013; on the Middle East by Budhwar and Mellahi, 2006; on Latin America by Elvira and Davila, 2005; on Central and Eastern Europe by Morley et al., 2008) and country-specific books on HRM such as on China (Cooke, 2012) and India (Budhwar and Bhatnagar, 2009) and on developing countries (e.g., Budhwar and Debrah, 2004). Further, there is an increasing number of HRM research articles being published in leading journals for specific EMs such as China and India. They cover a whole range of HR related topics such as expatriate management (e.g., Kim and Tung, 2013; Malek and Budhwar, 2012); strategic HRM (e.g., Zupan and Kase, 2005; Katou and Budhwar, 2010; Takeuchi et al., 2009); internationalisation, FDI and HRM (Khavul et al., 
2010; Wood et al., 2014); organisational capability for change (Judge et al., 2009); and working conditions in EMs (Connell and Burgess, 2013). To provide comprehensive literature on HRM in EMs is beyond the scope of this chapter, but we are very hopeful the various thematic chapters in this volume do so.

On related themes such as cultural 'cross-vergence' and WesternAfrican-Chinese HRM policy and practice in African organisations and the linkages between theoretical assumptions such as modernisation theory, dependency theory and postcolonial theory, have implications for organisations and management in Africa (Jackson et al., 2013) and other EMs. Jackson et al. (2013: 2518-2525) identify similarities and differences in cultural concepts such as African 'Ubuntu' and Chinese Confucianism in the context of these North-South interrelations. These include the adoption or adaptation and inward infusion of Western HRM practices such as performance management, reward and career management in emerging markets. Jackson et al. (2013) pose a number of vital questions such as what impact are Chinese organisations having in Africa; how are management decisions and actions contributing to employment opportunities, employability, skills and knowledge development; and what are partnerships or joint ventures between Chinese and African organisations contributing to mutual learning?

\section{MANAGING HUMAN RESOURCES IN EMERGING MARKETS - CHAPTER OUTLINES}

Three underlying theoretical or conceptual frameworks play a potentially vital part in understanding the nature and challenges of HRM in EMs. These are geopolitical, institutional/regulatory and cultural dynamics. All three are common threads of analysis in the various chapters of our work. In order to have meaningful contributions, which can help to get a comprehensive and comparative picture of the scene related to HRM in $\mathrm{EM}$, we provided the following chapter framework to all the contributors to develop their respective chapters.

Introduction and Background; Core issues pertinent to the chapter theme(s); Factors influencing core topic(s) of the chapter; Conceptual, theoretical and empirical developments; Key challenges for the HR function; Recommendations and way forward with the given context. Each chapter in the volume has been written by experts solely commissioned for it. 
Chapter 1 by Frank Horwitz and Pawan Budhwar outlines the development of emerging markets in the global context, different classifications of these markets, emphasising the growth trajectories of these markets and the shift in economic power from mature economies to emerging markets. They set out the importance and rationale for enhancing knowledge and research on HRM in these markets.

\section{HRM Theories and Approaches in Emerging Markets}

Chapter 2 by Geoffrey Wood and Frank Horwitz outlines theoretical and conceptual approaches to understanding human resource management and employment relations in selected emerging markets. Wood and Horwitz stress the value of institutional approaches and understanding labour markets in these economies.

Chapter 3 by Terence Jackson focuses on the importance of understanding cross-cultural issues in emerging markets. He provides an analysis of the case of China-Africa and South-South organisational interactions.

Chapter 4 by John Storey and Nceku Nyathi evaluates strategies and organisational structures of multinational firms from EMs. They outline organisational choices in respect of appropriate organisational design and structures, ownership and governance questions. Further, they assess new organisational structures and designs and cross boundary networks of IHRM in EMs.

\section{International HRM in Emerging Economies}

Chapter 5 by Mohan Thite describes the nature of emerging market multinational firms, IHRM policy and international management practice. Thite points to relevant research and organisational practice and gives case and comparative examples from BRICS countries such as China and Russia.

Chapter 6 by Randall S. Schuler, Shaista E. Khilji and Huub Ruël outlines the role of HRM in international mergers and acquisitions (M\&As) and international joint ventures in EMs. They set out the stages that organisations go through during international M\&As and joint ventures and the forms of organisational alliances in EMs.

Chapter 7 by Dennis R. Briscoe discusses the important area of expatriate integration and performance in emerging markets. Briscoe outlines the type of organisations which use expatriates, expatriate types and key issues pertaining to expatriates in both emerging and developed markets, including their deployment by EMMNCs. 
Chapter 8 by Rajesh Kumar and Jens Gammelgaard discusses approaches to negotiations in EMs. The authors delineate negotiation processes in EMs to show how the institutional environment (using the cases of China and India) influences particular approaches to negotiation.

\section{HRM Function and Systems in Emerging Markets}

Chapter 9 by Stella M. Nkomo, Yvonne du Plessis, Rana Haq and Francois du Plessis deals with the importance of understanding diversity, employment equity policy and practice in the BRICS nations. They also assess intra-nation and inter-nation practices in diversity management.

Chapter 10 by Agnieszka Skuza, Anthony McDonnell and Hugh Scullion discusses the important area of talent management in EMs. They discuss talent management in Central and Eastern Europe and barriers to effective talent management underlining the importance of dynamic contexts.

Chapter 11 by Emma Parry, Michael Dickmann, Julie Unite, Yan Shen and Jon Briscoe focuses on careers and career development in emerging markets. These authors compare characteristics of careers in developed countries and emerging markets considering contemporary careers, career transition and the particular dynamics of EMs and their impact on careers. In particular, they analyse career issues in China and South Africa.

Chapter 12 by Elaine Farndale, Susanne E. Beijer and Clare Kelliher deals with employee engagement in EMs. The authors define what is meant by employee engagement, its application in national contexts, extant research on employee engagement in emerging markets such as China and engagement in foreign MNCs operating in EMs.

Chapter 13 by Jaime Bonache and Carmen Paz-Aparicio deals with the compensation systems and total reward systems in EMs. They consider differences in international compensation identifying various types of compensation and their application in organisations across a range of emerging markets including BRICS countries.

Chapter 14 by Arup Varma, Pawan Budhwar and Sneha Singh deals with performance management and high performance work systems. The authors evaluate different forms of performance management in emerging market contexts.

\section{Comparative and Regional HRM Perspective in Emerging Markets}

Chapter 15 and three subsequent chapters focus on regional HRM perspectives in emerging markets. In Chapter 15 Fang Lee Cooke and 
Pawan Budhwar evaluate HRM policy and practice in China and India. They assess the institutional environments of these respective countries, employment relations and identify key HRM challenges such as skills shortages and talent retention.

Chapter 16 by Khalil M. Dirani, Alexandre Ardichvili, Maria Cseh and Elena Zavyalova critically evaluates HRM in Russia, Central and Eastern Europe. They discuss theory building perspectives and detailed country-specific HRM policy and practice and take into account institutional and legislative contexts and questions of convergence and divergence.

Chapter 17 by Anabella Davila and Marta M. Elvira assesses HRM in Latin America. They discuss the importance of kinship, social networks and staffing practices, the culture, power and authority, HRM, training and development and employment relations.

Chapter 18 by Florence Y.A. Ellis, Richard B. Nyuur and Yaw A. Debrah deals with HRM in Africa. The authors explain the diversity regarding HRM practice in African countries. They refer to relevant research, the relationship between business context and HRM practices such as recruitment and selection, training and development, reward and performance management, labour markets and employment relations.

\section{Emerging Themes, Issues and the Future of HRM in Emerging Markets}

Chapter 19 and the remaining two chapters deal with emerging themes, issues and the future of HRM in emerging markets. In Chapter 19 Vasanthi Srinivasan and Bimal Arora examine HRM and corporate social responsibility (CSR) linkages in the context of emerging markets. Their focus is on the Indian case, evaluating CSR as organisational strategy and its implementation.

Chapter 20 by Chris Brewster, Wolfgang Mayrhofer and Fang Lee Cooke provides a research-based discussion on convergence, divergence and the diffusion of HRM in EMs. They look at what distinguishes HRM in emerging markets considering factors such as societal culture, labour markets, work intensification and demand for skills. They also assess the key issues of convergence and divergence in respect of local HRM practice and those of Western MNCs.

Chapter 21 by Frank Horwitz, Pawan Budhwar and Michael J. Morley identifies future HRM trends in emerging markets, key issues and challenges for further research and practice.

We sincerely hope that this book serves as a catalyst to the development of further theoretical insights and appropriate techniques of HRM 


\section{Handbook of HRM in emerging markets}

in the EMs context. The subject area of the book is suitable for both undergraduate and postgraduate HRM, International HRM and International Management courses. In addition, this book will be of interest to cross-national HRM researchers and practitioners.

We would like to thank all those who have in various ways helped to make this project a success. Our special thanks to Edward Elgar Publishing for accepting our proposal on this project and also to colleagues who have contributed towards the development of the chapters in this volume. Further, we would like to thank Emily Mew, Harry Fabian, Sarah Cook and Dr Madhubanti Bhattacharyya at Edward Elgar Publishing for their help and assistance at various stages of the production of this book.

\section{REFERENCES}

Bailey, A (2010) New Locations - Next Eleven (N-11). International HR Advisor, Autumn, pp. 2-3.

Berger, R. (2012) Human Resources: How the Emerging Markets are Changing the Global HR Agenda. Think: Act Study 33. Roland Berger Strategy Consultants.

Briscoe, D, (2013) Emerging Market Terminology. Unpublished Manuscript (27 April), pp. 1-11.

Budhwar, P. and Bhatnagar, J. (2009) The Changing Face of People Management in India. London: Routledge. Budhwar, P. and Debrah, Y. (eds) (2004) HRM in Developing Countries. London: Routledge.

Budhwar, P. and Mellahi, K. (2006) Managing Human Resources in the Middle-East. London: Routledge.

Chattopadhyay, A., Batra, R. and Ozsomer, A. (2012) The New Emerging Market Multinationals. New York: McGraw-Hill.

Connell, J. and Burgess, J. (2013) Vulnerable Workers in Emerging Middle Eastern Economy: What are the Implications for HRM? International Journal of Human Resource Management, 24(22): 4166-4184.

Cooke, Fang Lee (2012). Human Resource Management in China. London: Routledge.

Das, S. (2013) An Emerging Market Crisis is Looming. Sifi.com (28 October 2013).

The Economist (2011a) Economic Focus - How the BRICS were baked.10 December, p. 84.

The Economist (2011b) Nipping at Their Heels. 22 January, p. 79.

The Economist (2012a) Brazil in Africa. 10 November, pp. 70-71.

The Economist (2012b) BRICS Countries Selected Economic Indicators. IMF and Economist Intelligence Unit, 29 September, pp. 4, 8, 11, 29, 49.

The Economist (2012c) Economic and Financial Indicators. 1 December, p. 100.

The Economist (2012d) The World in 2060. 10 November, p. 77.

The Economist (2013a) A World Turned Upside Down. 21 September, pp. 15-16.

The Economist (2013b) China's Outward Investment - The Second Wave. 26 October, pp. 70-72.

The Economist (2013c) Elephants and Tigers - India and Africa. 26 October, pp. 55-56.

The Economist (2013d) The Best Since Sliced Bread. 19 January, p. 68.

Elvira, M. and Davila, A. (2005) Managing Human Resources in Latin America. London: Routledge. 
Fengler, W. (2012) Quoted in 'Africa's Economy - Bulging in the middle'. The Economist, 20 October, p. 49.

Goldman Sachs (2010) Emerging Markets Equity in Two Decades: A Changing Landscape. Global Economic Paper, 204, retrieved from: http://www.dasinvestment.com/ fileadmin/images/pictures/0809_Global_Econ_Paper_No_204_Final.pdf (accessed 29 August 2014).

Hewlett, S.A. and Rashid, R. (2011) Winning the War for Talent in Emerging Markets. Boston, MA: Harvard Business School Publishing.

Horwitz, F.M. (2012) Evolving Human Resource Management in Southern African Multinational Firms: Towards an Afro-Asian Nexus. International Journal of Human Resource Management, 23(14): 2938-2958.

Horwitz, F.M. and Mellahi, K. (2009) Human Resource Management in Emerging Markets. In Collings, D.G. and Wood, G. (eds) Human Resource Management: A Critical Approach, London: Routledge: 263-295.

International Labour Organization (2011) Global Employment Trends, 2012, retrieved in 2012 from: http://www.ilo.org/wcmsp5/groups/public/@dgreports/@dcomm/@publ/ documents/publication/wcms_171571.pdf.

Jackson, T., Louw, L. and Zhao, S. (2013) China in Sub-Saharan Africa: Implications for HRM Policy and Practice at Organisational Level. International Journal of Human Resource Management, 24(13): 2512-2533.

Judge, W.Q., Naoumova, I. and Douglas, T. (2009) Organizational Capacity for Change and Firm Performance in a Transitional Economy. International Journal of Human Resource Management, 20(8): 1737-1752.

Kamoche, K., Debrah, Y., Horwitz, F.M. and Muuka, G (eds) (2004) Managing Human Resources in Africa. London: Routledge.

Katou, A. and Budhwar, P. (2010) Testing Competing HRM-Performance Linkage Models: Evidence from the Greek Manufacturing Sector. The European Journal of International Management, 4(5): 464-487.

Khavul, S., Benson, G.S. and Datta, D.K. (2010) Is Internationalization Associated with Investments in HRM? A Study of Entrepreneurial Firms in Emerging Markets. Human Resource Management, 49(4): 693-713.

Kim, H-D. and Tung, R. (2013) Opportunities and Challenges for Expatriates in Emerging Markets: An Exploratory Study of Korean Expatriates in India. International Journal of Human Resource Management, 24(5): 1029-1050.

Kupka, B., Briscoe, D.R. and Everett, A.M. (2013) Influences of International Business Conditions in International Human Resource Strategies for Africa. Annual Conference of Pan-Pacific Business Association, Johannesburg, 5 June.

Lustig, N. (2012) Gini Back in the Bottle. The Economist, Special Report on the World Economy, 13 October, pp. 20-21.

Malek, M.A. and Budhwar, P. (2012) Cultural Intelligence as a Predictor of Expatriate Adjustment and Performance in Malaysia. Journal of World Business, 48: 222-231.

McRae, H. (2010) The Subtle Hand We Must Play on Trade. The Independent, 28 July, p. 5.

Morley, M., Heraty, N. and Michallova, S. (2008) Managing Human Resources in Central and Eastern Europe. London: Routledge.

PTI (2014) BRICS Pack a Good Initiative by Emerging Nations: Joseph Stiglitz. Press Trust of India, 14 January.

Quelch, J.A. and Jocz, K.E. (2012) All Business is Local. Portfolio Penguin: London, pp. 1-27.

Reuters (2014) Emerging Markets Outlook not Rosy, but Valuations Tempt. 4 February.

Takeuchi, N., Checn, Z. and Lam, W. (2009) Coping with an Emerging Market Competition Through Strategy-Human Resource Alignment: Case Study Evidence from Five 


\section{Handbook of HRM in emerging markets}

Leading Japanese Manufacturers in the People's Republic of China. International Journal of Human Resource Management, 20(12): 2454-2470.

Varma, A. and Budhwar, P. (eds) (2013) Managing Human Resources in Asia-Pacific. Routledge: London.

Wood, G., Mazouz, K., Yin, S. and Cheah, J.E-T. (2014) Foreign Direct Investment from Emerging Markets to Africa: The HRM Context. Human Resource Management, 53: 171-201.

van Agtmael, A. (2007) The Emerging Markets Century. London: Simon \& Schuster.

Zupan, N. and Kase, R. (2005) Strategic Human Resource Management in European Transitional Economies: Building a Conceptual Model on the Case of Slovenia. International Journal of Human Resource Management, 16(6): 882-906. 